\title{
Found Law, Made Law and Creation: Reconsidering Blackstone's Declaratory Theory
}

\author{
Daniel M. Filler \\ Drexel University - Thomas R. Kline School of Law, daniel.m.filler@drexel.edu \\ William S. Brewbaker III \\ University of Alabama - School of Law, wbrewbak@law.ua.edu
}

Follow this and additional works at: https://scholarship.law.ua.edu/fac_working_papers

\section{Recommended Citation}

Daniel M. Filler \& William S. Brewbaker III, Found Law, Made Law and Creation: Reconsidering Blackstone's Declaratory Theory, (2006).

Available at: https://scholarship.law.ua.edu/fac_working_papers/22

This Working Paper is brought to you for free and open access by the Faculty Scholarship at Alabama Law Scholarly Commons. It has been accepted for inclusion in Working Papers by an authorized administrator of Alabama Law Scholarly Commons. 


\title{
THE UNIVERSITY OF ALABAMA SCHOOL OF LAW
}

\author{
FOUND LAW, MADE LAW AND \\ CREATION: RECONSIDERING \\ BLACKSTONE'S DECLARATORY \\ THEORY
}

WILLIAM S. BREWBAKER III

XXII JOURNAL OF LAW \& RELIGION 255

This paper can be downloaded without charge from the Social Science Research Network Electronic Paper Collection: http://ssrn.com/abstract=899103 


\title{
FOUND LAW, MADE LAW AND CREATION: RECONSIDERING BLACKSTONE'S DECLARATORY THEORY
}

\author{
William S. Brewbaker III
}

Sir William Blackstone's Commentaries on the Laws of England is arguably the single most influential work of jurisprudence in American history. ${ }^{1}$ Written in the late eighteenth century, it regularly appeared in American law school classrooms up until the early part of the twentieth century, when ridiculing Blackstone and the Commentaries became a part of legal academic orthodoxy and the influence of the Commentaries waned. ${ }^{2}$ Blackstone eventually became the poster child for everything

* Professor of Law, University of Alabama. With the usual disclaimer, I am grateful to Al Brophy, Bob Cochran, Jeff Powell, Susan Randall, David Skeel, Norman Stein and an anonymous peer reviewer for helpful comments on earlier drafts of this paper. Thanks are also due to Dean Ken Randall and the University of Alabama Law School Foundation for generous research support. An earlier version of this paper was delivered at the Christian Legal Scholars' Symposium in McLean, Virginia on October 29, 2004.

1. See e.g. Daniel J. Boorstin, The Mysterious Science of the Law 3-4 (U. Chi. Press 1941) (characterizing the Commentaries the "bible of American lawyers" during the days of the early Republic). Boorstin nevertheless does not think much of Blackstone: "Blackstone was not a rigorous thinker, and his work does not rank with the great books which demonstrate the nicest intricacies of the mind of man." Id. at 189.

Nevertheless, Blackstone is not without his defenders, even in academically respectable circles. Albert Alschuler has argued persuasively that Blackstone's treatment at the hands of his critics has been less a critique than a caricature. See Albert W. Alschuler, Rediscovering Blackstone, 145 U. Pa. L. Rev. 1 (1996). There is other evidence that Blackstone's reputation may be recovering slightly. See e.g. Carol M. Rose, Canons of Property Talk, or Blackstone's Anxiety, 108 Yale L.J. 601 (1998); Rupert Cross, Blackstone v. Bentham, 92 L. Q. Rev. 516 (1976); Wilfrid Prest, Blackstone as Architect: Constructing the Commentaries, 15 Yale J.L. \& Humanities 103 (2003); Harold J. Berman \& Charles J. Reid, Jr., The Transformation of English Legal Science: From Hale to Blackstone, 45 Emory L.J. 437, 489-497 (1996); Herbert J. Storing, William Blackstone, in History of Political Philosophy 622-634 (Leo Strauss \& Joseph Cropsey eds., 3d ed., U. Chi. Press 1987); S.F.C. Milsom, The Nature of Blackstone's Achievement, 1 Oxford J. Leg. Stud. 1 (1981).

Blackstone did not subscribe to the "brooding omnipresence" theory of law or suggest that natural law provided a basis from which judges could deduce answers to complex legal questions. His accounts of property rights and the relationship between the individual and the community are also more complex than they are usually portrayed. Alschuler, supra at 19-36, 4454. Alschuler also argues that Blackstone presented the declaratory theory "with a wink and a nod." See id. at 37. (2000):

2. See e.g. Stephen Skinner, Blackstone's Support for the Militia, 44 Am. J. Legal Hist. 1

Blackstone himself has not been treated gently by posterity, being described as a failure at the bar at the outset of his career and an inadequate judge at the end. He has been 
that the realists and their descendants ${ }^{3}$ thought was wrong with American law-formalism, natural rights and plutocracy. ${ }^{4}$

Both Blackstone's admirers and his detractors have devoted significant attention to his famous account of judging, which holds that judges find (or declare) law rather than make law. In the introduction to the Commentaries, Blackstone states that the judge's job is to determine the law "not according to his own private judgment, but according to the known laws and customs of the land;" the judge is "not delegated to pronounce a new law, but to maintain and expound the old one." One reason Blackstone's account has been attractive in some quarters is because it supplies apparent answers to a number of problems raised by the idea of judge-made law. If judges merely find and apply authoritative law, their decisions presumptively carry the authority of the

described as "not a particularly successful politician" during his time in Parliament, while as a lecturer he has been said to have been "by no means a scientific jurist" having "only the vaguest possible grasp of elementary conceptions of law." Moreover his Commentaries have been criticised for unoriginality and even plagiarism. However, attention has never wandered far from Blackstone's work, and various studies have focused on the Commentaries as both a legal source and an object of critical study, all the more so in recent analyses of eighteenth-century legal thought.

Id. at 1-2 (notes omitted). As early as 1840, the English humor magazine Punch published a series of satirical articles on the Commentaries later published (and recently republished) as the book Gilbert A'Beckett, Arthur A'Beckett \& Harry Furniss, The Comic Blackstone (new \& rev. ed., Ashford 1985) (1998). See David A. Lockmiller, Sir William Blackstone 158 (U. N.C. Press 1938) (P. Smith 1970).

3. Blackstone was also attacked by the realists' forebears-most famously by Jeremy Bentham and John Austin. See generally Jeremy Bentham, A Fragment on Government and an Introduction to the Principles of Morals and Legislation (Wilfrid Harrison ed., 2d prtg., Basil Blackwell 1967) (critique of the Commentaries); Jeremy Bentham, Anarchical Fallacies, in The Collected Works of Jeremy Bentham vol. 2, 501 (Oxford U. Press 1983) (characterizing natural rights as "nonsense upon stilts"); John Austin, The Province of Jurisprudence Determined and the Uses of the Study of Jurisprudence 184-187 (1832) (Isaiah Berlin, Stuart Hampshire, Richard Wollheim eds., Weidenfeld \& Nicolson 1955). It has been argued that the realists and crits are opposed to positivism, in which case it might be wrong to characterize Bentham as a forebear. See e.g. Jeffrey A. Standen, Critical Legal Studies as an Anti-Positivist Phenomenon, 72 Va. L. Rev. 983 (1986); but see Harold J. Berman, Toward an Integrative Jurisprudence: Politics, Morality, History, in Faith and Order: The Reconciliation of Law and Religion 289, 291, n. 2 (Scholars Press 1993) (arguing that the realists and the positivists share the same definition of law).

4. See generally Duncan Kennedy, The Structure of Blackstone's Commentaries, 28 Buff. L. Rev. 205 (1979). Kennedy characterizes the Commentaries as:

quite patently attempt[ing] to "naturalize" purely social phenomena. They restate as

"freedom" what we see as servitude. And they cast as rational order what we see as something like chaos.... [C]ritics have linked these traits ... to Blackstone's desire to legitimate the legal status quo of the England of his day.

Id. at 211. But cf. William Blackstone, Commentaries on the Laws of England vol. 2, 11 (U. Chi. Press 1979) (arguing that the right of inheritance is not a natural right but is a "political establishment" based on "long and inveterate custom").

5. Blackstone, supra n. 5, at vol. 1, 69. 
law they are applying. Because the law pre-exists the decision, the specter of retroactive liability disappears. On the other hand, if the judges make the law (or worse yet, "make it up"), the law's legitimacy is called into question. The idea that individual judges are free to impose their own views about sound social policy in the name of deciding controversies between individual litigants is potentially anti-democratic. ${ }^{6}$ The dictum that it is the province of the courts to "say what the law is"7 may be unobjectionable as long as the judge is a technician using agreed-upon rules of recognition to "find" the law outside herself; otherwise, it smacks of judicial supremacy. ${ }^{8}$

Despite its rejection in other circles, Blackstone's account of judging has remained popular with some American evangelical Christians. $^{9} \quad$ Evangelicals have historical, political and theological reasons to be attracted to the declaratory theory. Although rejection of Blackstone's declaratory theory requires neither moral antirealism nor a commitment to the secularization of law, many of Blackstone's early critics were committed to one or both of those positions. ${ }^{10}$ As an historical matter, Blackstone and evangelicals may have shared common cultural opponents. Politically, evangelicalism continues to be heavily influenced by Enlightenment liberal commitments to democracy and individual rights ${ }^{11}$ that are consistent with the broad outlines of

6. It may not be inconsistent with some conceptions of democracy, particularly if judges are elected or legislators are free to change judge-made rules.

7. Marbury v. Madison, 5 U.S. 137, 177 (1803). ("It is emphatically the province and duty of the judicial department to say what the law is.").

8. See Benjamin Hoadly, The Nature of the Kingdom, or Church, of Christ: A Sermon Preach'd before the King, at the Royal Chapel at St James, on Sunday March 31, 1717, at 12 (William Bradford 1717) ("[W]hoever hath an absolute authority to interpret any written, or spoken Laws; it is He, who is truly the Law-Giver, to all Intents and Purposes; and not the Person who first wrote, or spoke them."). John Chipman Gray quotes Hoadly's sermon in the course of arguing that the law can be reduced to "the rules by which the courts decide cases." John Chipman Gray, The Nature and Sources of Law 102 (Roland Gray ed., 2d ed., MacMillan Co. 1921).

9. See e.g. Herbert W. Titus, God, Man and Law: The Biblical Principles 41-47, 53-56, 62 (Inst. Basic Life Principles 1994); John W. Whitehead, The Second American Revolution 30-32, 47-49 (David C. Cook Publg. Co. 1982); Craig A. Stern, The Common Law and the Religious Foundations of the Rule of Law Before Casey, 38 U.S.F. L. Rev. 499, 509-511 (2004). A wellknown contemporary exponent of Blackstone's declaratory theory is former Alabama Chief Justice Roy Moore. See generally Roy Moore \& John Perry, So Help Me God: The Ten Commandments, Judicial Tyranny, and the Battle for Religious Freedom (Broadman \& Holman 2005).

10. See infra n. 64 .

11. See Mark A. Noll, The Scandal of the Evangelical Mind 67-76 (William B. Eerdmans Publg. Co. 1994) (arguing that American evangelical political thought was influenced by a republican theory of politics, a democratic understanding of society, and a liberal view of the economy). 
Blackstone's thought, if not with all the particulars. ${ }^{12}$ Theologically, Blackstone's commitments to divine law as the root of law in general, ${ }^{13}$ to the Christian account of humanity as fallen and corrupt, ${ }^{14}$ and to the authority of the Bible ${ }^{15}$ are all congenial to evangelical faith.

The main purpose of this paper is not to argue that Blackstone's declaratory theory of law is deficient as an account of what lawyers do (although I agree that it is), ${ }^{16}$ but rather that it is deficient as a matter of Christian theology, especially the theology of creation. It may come as a shock to culture warriors to learn that the doctrine of creation is unfamiliar territory for many evangelicals. Talk about creation in America today is so thoroughly dominated by discussions of evolutionary theory, the age of the earth, and other similar "religion vs. science" issues ${ }^{17}$ that the traditional implications of the theology of

12. As Alschuler notes, American lawyers and politicians found much to criticize in the Commentaries. Alschuler, supra n. 1, at 8-14. Indeed, Robert Cover has observed that St. George Tucker's American edition of Blackstone "was not only a publication of the Blackstone text but also an engagement of it in combat." Id. at 12.

13.

This law of nature, being co-eval with mankind and dictated by God himself, is of course superior in obligation to any other. It is binding over all the globe, in all countries, and at all times: no human laws are of any validity, if contrary to this; and such of them as are valid derive all their force, and all their authority, mediately or immediately, from this original.

Blackstone, supra n. 4, at vol. 1, 41 .

14.

And if our reason were always, as in our first ancestor before his transgression, clear and perfect, unruffled by passions, unclouded by prejudice, unimpaired by disease or intemperance, the task would be pleasant and easy; we should need no other guide but this. But every man now finds the contrary in his own experience; that his reason is corrupt, and his understanding full of ignorance and error.

Id.

15.

[D]ivine providence; ... in compassion to the frailty, the imperfection, and the blindness of human reason, hath been pleased ... to discover and enforce it's [sic] laws by an immediate and direct revelation. The doctrines thus delivered we call the revealed or divine law, and they are to be found only in the holy scriptures. These precepts, when revealed, are found upon comparison to be really a part of the original law of nature, as they tend in all their consequences to man's felicity. But we are not from thence to conclude that the knowledge of these truths was attainable by reason, in it's [sic] present corrupted state; since we find that, until they were revealed they were hid from the wisdom of ages.... Yet undoubtedly the revealed law is (humanly speaking) of infinitely more authority than what we generally call the natural law. Because one is the law of nature, expressly declared to be by God himself; the other is only what, by the assistance of human reason, we imagine to be that law. If we could be as certain of the latter as we are of the former, both would have an equal authority; but, till then, they can never be put in any competition together.

Id. at 41-42.

16. Cf. Gray, supra n. 8, at 219-232 (criticizing Blackstone in light of judicial lawmaking).

17. Not surprisingly, the Christian theology of creation has long been a point of engagement between scientists and theologians. See e.g. Augustine, The City of God against the Pagans 449- 
creation have been neglected, if not forgotten altogether. ${ }^{18}$ There are, of course, multiple Christian theologies, but the principles drawn upon here-though often neglected - are relatively uncontroversial across the Christian tradition and should not be controversial among evangelicals or other Christians attracted to declaratory theories of one sort or another.

The discussion of creation theology and law presented here focuses on four primary Christian theological claims. First, Christians have generally held that the created order is contingent, meaning that God might well have chosen not to create the world and was not constrained by anything outside himself in the way it was created. As a result, the shape of the world cannot be predicted in advance, whether on the basis of the nature of God's being, the nature of logical thought, or the nature of eternal matter co-existing with God; rather, the world (including but not limited to human artifacts like laws) must be studied in all its particularity in order to be understood. Second, this particular, contingent world was made to flourish under (and only under) human rule. Human rule may be summarized under the idea of dominion - the limited, respectful rule appropriate to human beings given the kind of beings we are, the world in which we have been placed, and our capacity for relationship with our Creator. If human rule (despite its potential for abuse) is not intrinsically evil, then we need not be surprised that our rulers (even our judges) make law and do not merely find it. By the same token, God is the only autonomous creator-human rule takes place in an environment of moral order and accountability.

Third, because God is distinct from the creation, human rulers need not have godlike capacities in order to rule legitimately. Human beings are neither omniscient nor infinitely wise or free. Our limitations suggest that our civil laws need not be, indeed cannot be, universal and eternal, and our judges need not be oracles of deeper realities that are inaccessible to the rest of us. Finally, human activity takes place in the context of the unfolding story of God's actions in redemptive history; while human institutions (including those related to law and politics) have intrinsic dignity and important consequences, they cannot but be transitory and provisional, anticipating the fuller justice of divine rule in

497 (426) (R.W. Dyson ed., Cambridge U. Press 1998) (originally published 426).

18. Orthodox Christianity entails belief in a personal God who brought this world, and not another, into being. Nothing, however, in the account of creation set forth in this Article (so far as I am aware) turns on one's acceptance or rejection of evolutionary theory. But cf. Titus, supra $\mathrm{n}$. 9, at 3-15; Whitehead, supra n. 9, at 46-48 (arguing that evolutionary theory has had a negative influence on law). 
the age to come.

In Part I of this Article, I review Blackstone's account of the declaratory theory. Part II explains some of the reasons for evangelicals' attraction to Blackstone. I will sometimes refer to the declaratory theory as a "Found Law" conception of judging, in contrast with conceptions of judging that are more open about the active role that judges play in making law ("Made Law" conceptions). There are, to be sure, many different accounts of how judges find or make the law, and the best do not fit squarely into either category. ${ }^{19}$ I focus on Blackstone's particular version of the declaratory theory because of its historical importance and because it helps illuminate the key misunderstandings of Christian theology of creation that are explored in Part III.

The discussion in this Article is limited in two important respects. First, the account of human law $^{20}$ examined here is confined almost exclusively to the activities of the judge in the Anglo-American legal tradition. $^{21}$ Second, it is not my aim to offer a comprehensive theology of human law, even one limited to the task of the judge as conceived in the Anglo-American tradition. ${ }^{22}$ Nevertheless, as I have suggested, the traditional Christian understanding of creation has been largely lost in modern Western culture, even within the church. Its recovery may enhance reflection about the nature of law and the task of the judge.

As suggested earlier, any appropriate theological account of judging, theological or otherwise, must be one that can be squared with the observed world. A major weakness of the declaratory theory is its implausibility as an account of what judges and lawyers actually do. To be sure, in our legal tradition, not every case is a "hard case;" many cases are presumably never litigated because competent lawyers can agree on what the law is. In such cases, the judge and the lawyer may be said to find or discover the law. Even here, if the law being "found" is

19. See e.g. John Finnis, The Truth in Legal Positivism, in The Autonomy of Law: Essays on Legal Positivism 195-214 (Robert P. George ed., Oxford U. Press 1996) (analyzing Aquinas' characterization of positive law as a human creation in key respects).

20. I use human law interchangeably with positive or municipal law, as distinguished from divine law or natural law.

21. I do not address statutory and constitutional interpretation, which present important, though not unrelated, additional questions.

22. A full theological account of judging, much less of law generally, would have to consider not only the theology of creation, but also other important features of Christian doctrine such as redemption, the human person, eschatology, the meaning of Israel's theocracy, hermeneutics, etc. For a recent full-orbed evangelical political theology, see generally Oliver O'Donovan, The Desire of the Nations: Rediscovering the Roots of Political Theology (Cambridge U. Press 1996); Oliver O'Donovan, The Ways of Judgment: The Bampton Lectures, 2003 (William B. Eerdmans Publg. Co. 2005). 
judge-made, questions remain about its authority and the appropriateness of its continued application. ${ }^{23}$ On the other hand, courts make many decisions about relatively mundane, but unsettled, legal matters. When a judge is asked to choose a rule of decision in a case of first impression involving the scope of a homeowners' association's authority ${ }^{24}$ or disclosures owed in the physician-patient relationship, ${ }^{25}$ the declaratory theory does not seem to describe the judicial enterprise very well. Rather than saying that the judge is discovering a preexisting (and presumably findable) right answer and handing it down, it seems far more accurate to say that the judge is doing his best to make a good decision given the legal and practical context of the decision.

Despite the declaratory theory's inadequacies, its emphasis on the importance of law's external givenness in relation to the judge and the importance of rules for legal decision-making are well-known strengths. ${ }^{26}$ Whatever their official position about the declaratory theory, lawyers and judges routinely act as if legal argumentation matters, and complaints about judicial incompetence, partisanship or activism, presuppose some conception of constrained judging. This Article does not attempt to provide a systematic account of the appropriate relationship between form and freedom in the judicial process. Nevertheless, in the Conclusion, I outline what I take to be the main elements of truth in the declaratory theory and offer some suggestions as to the possible contributions a theology of creation might make to a more satisfying account of judge-made law-i.e., one that

23. The obvious question is where the prior judge(s) "found" the law that is merely "applied" in the case. Note, however, that this problem is not necessarily solved even where the judge is applying a democratically-enacted statute in an easy case. The question remains: What gives the statute authority? The latter question is not usually asked because our commitment to democracy is often uncritical (this is not to say unfounded). See O'Donovan, The Desire of the Nations, supra $\mathrm{n}$. 22, at 20 (arguing that accounts of political authority should focus on political acts rather than institutional structure).

24. See e.g. Verna v. Links at Valleybrook Neighborhood Assn, Inc., 852 A.2d 202, 205 (N.J. Super. App. Div. 2004) (case involving three matters of first impression in New Jersey):

(a) whether a homeowners association, having previously ceded jurisdiction of its streets

to a municipality, retains the authority to enforce its own parking regulations, (b)

whether such an association's board of directors exceeds its authority to conduct

elections when it issues a "candidate audit" advising unit owners which of the candidates

were members in "good standing," and (c) whether, when asserting a defamation claim, a

candidate for election to an association's board of directors should be considered a

"public figure."

25. See e.g. DeGennaro v. Tandon, 873 A.2d 191 (Conn. App. 2005) (whether health care provider is obligated to disclose provider-specific risks in addition to the ordinary risks accompanying a given procedure).

26. These are strengths which, as I have suggested, need not be entirely absent in a Made Law theory. See Finnis, supra n. 19, and accompanying text. 
does justice to both judicial freedom and constraint.

\section{ThE BLACKSTONIAN JUdGE}

Blackstone's declaratory theory has been justly criticized, although occasionally for the wrong reasons. A common misconception is that Blackstone believes in the "brooding omnipresence" theory of law parodied, for example, by Justice Holmes in Southern Pacific Railway Co. v. Jensen. ${ }^{27}$ As we shall see, one of the overriding concerns in Blackstone's account of judicial methodology is to ensure that judges' decisions are guided by sources other than personal opinions about what good law ought to be. As a result, Blackstone relies heavily on legal custom and precedent, both of which are tied to the specific acts of concrete human beings in particular times and places.

My main argument will be that one of the things that makes Blackstone's declaratory theory unpersuasive is the strong resemblance in his account between the task of the legislator and that of the judge. In Blackstone's vision, both legislators and judges are constrained by external moral/legal principles, and both likewise exercise discretion. Even so, Blackstone insists officially that judges only declare the law, while he is prepared to admit that legislators make law.

Blackstone's account of common-law judge's task entails eight main claims: (1) English common law is authoritative because it is ancient custom, ${ }^{28}(2)$ judges are "the depositaries of the laws; the living oracles who must decide in all cases of doubt", ${ }^{29}$ (3) judges must decide "not according to [their] own private judgment but according to the known laws and customs of the land"; $;^{30}$ (4) judges find the law of the land by drawing on "experience and study;... and from being long personally accustomed to the judicial decisions of their predecessors"; (5) judicial decisions are not themselves law, but are "the principal and most authoritative evidence, that can be given, of the existence of such ... custom"; $;{ }^{31}$ (6) precedents are to be followed both for the sake of stability and because the prior decision has settled "what before was

27. "The common law is not a brooding omnipresence in the sky, but the articulate voice of some sovereign or quasi sovereign that can be identified ..." S.P. Co. v. Jensen, 244 U.S. 205, 222 (1917) (Holmes, J., dissenting); see also Linkletter v. Walker, 381 U.S. 618, 622-624 (1965) (contrasting Blackstone's declaratory theory with John Austin's account of interstitial judge-made law).

28. Blackstone, supra n. 4, at vol. 1,67.

29. Id. at 69 .

30. Id. at 69 .

31. Id. 
uncertain and perhaps indifferent" ${ }^{\prime 2}$ and made it a "permanent rule"; 33 (7) the only justification for departure from precedent is that it is contrary to reason or divine law, in which case the judges are not making a new law, but "vindicat[ing] the old one from misrepresentation"; ${ }^{34}(8)$ in such cases, the prior precedent was "not law" because it was not "the established custom of the realm." 35

As an initial matter, it is worth noting that Blackstone discusses judicial methodology separately from legal authority. Although Blackstone devotes a great deal of section two of the Introduction to the Commentaries $^{36}$ to natural and divine law and their relationship to human laws, the account he provides of what judges do is found in section three, ${ }^{37}$ which is concerned with the laws of England. Blackstone's description of judicial method in section three is surprisingly positivistic given section two's emphasis on natural and divine law. On the face of Blackstone's account in section three, the common law is not based in any direct way on ruminations about human nature or other features of the created order, or even on the Bible. ${ }^{38}$

32. Matters that are "indifferent" are neither good nor bad in themselves. The Oxford English Dictionary Online indifferent, a. ${ }^{1}$, def 17, http://dictionary.oed.com/cgi/entry/50115308?query_ type $=$ word\&queryword=indifferent \&first=1\&max_to_show=10\&sort_type=alpha\&result_place $=$ 1\&search_id=EvzV-EIDFAO-7557\&hilite=50115308 (Oxford U. Press 2006) (1989).

33. Blackstone, supra n. 4, at vol. 1, 69.

34. Id. at $69-70$.

35. Id. at 70 .

36. Id. at $38-62$.

37. Id. at 63-92.

38. But cf. § 2:

Upon these two foundations, the law of nature and the law of revelation, depend all human laws; that is to say, no human laws should be suffered to contradict these. There is, it is true, a great number of indifferent points, in which both the divine law and the natural leave a man at his own liberty; but which are found necessary for the benefit of society to be restrained within certain limits. And herein it is that human laws have their greatest force and efficacy; for, with regard to such points as are not indifferent, human laws are only declaratory of, and act in subordination to, the former. To instance in the case of murder: this is expressly forbidden by the divine, and demonstrably by the natural law; and from these prohibitions arises the true unlawfulness of this crime. Those human laws, that annex a punishment to it, do not at all increase it's [sic] moral guilt, or superadd any fresh obligation in foro conscientiae to abstain from it's [sic] perpetration.... But with respect to matters that are in themselves indifferent, and are not commanded or forbidden by those superior laws; ... here the inferior legislature has scope and opportunity to interpose, and to make that action unlawful which before was not so.

Id. at 42-43. See also id. at 54-55, where Blackstone argues that in the case of legislation prohibiting crimes mala in se,

the legislature ... acts only ... in subordination to the great lawgiver, transcribing and publishing his precepts. So that, upon the whole, the declaratory part of the municipal law has no force or operation at all, with regard to actions that are naturally and intrinsically right or wrong. 
Rather, it is based on the legal customs of the English people, as they have evolved over time. ${ }^{39}$ The principal evidence of legal custom is the written decisions of the courts. In most cases, "finding" the law presumably consists of reading and applying the reported decisions.

This works well enough for the easy cases, but what about the hard ones (which Blackstone refers to as "cases of doubt")? ${ }^{40}$ Here, Blackstone's description of what judges do is obscure. $\mathrm{He}$ acknowledges that the judges must "decide" in such cases, but they are to decide "according to the law of the land," which they know from "long experience and study." 41 What is left unanswered is how judges are to decide "according to the law of the land" in cases for which there is, as yet, no governing decision.

It is sometimes suggested that Blackstone's model for decision in such cases is the Newtonian empiricism of his day. ${ }^{42}$ Just as the Newtonian scientist mines empirical evidence in search of underlying principles that enable prediction of future events, the Blackstonian judge

39. See e.g. Blackstone's treatment of inheritance rights and marital property. In both cases, he says that English custom, while permissible, is not based on natural right. Indeed, in connection with inheritance law, he notes that "we often mistake for nature what we find established by long and inveterate custom." Id. at vol. 2, 11. See also id. at vol. 1, 55 (marital property laws and offense of monopolization not grounded in nature). See also Alschuler, supra n. 1, at 37-43 (noting Blackstone's emphasis on the historical origins of legal doctrines and his openness to legal reform).

40. Blackstone, supra n. 4 , at vol. 1, 69.

41. Id.

42. See Harold J. Berman, Law and Revolution, II 299 (Belknap Press 2003). Berman describes the methodology of Newtonian science as follows:

Newton stated that his method of investigation of the laws governing gravity and other active forces in nature involved three major steps: (1) the derivation of general principles

("laws") from empirical evidence, (2) the extension of those principles by mathematical procedures, and (3) the deduction of as yet unaccounted for facts from the general statement of the theory.

See also Boorstin, supra n. 1, at 12 ("Blackstone was, in a sense, doing for the English legal system what Newton had done for the physical world, and what Locke had done for the world of the mind."). There is only a little textual support for this view. In $\S 1$ of the Introduction to the Commentaries, Blackstone's inaugural lecture as Vinerian professor is reproduced. In it, he speaks of "the science ... committed to his [Blackstone's] charge, to be cultivated, methodized, and explained ...," Blackstone, supra n. 4, at vol. 4, and urges students to "lay the foundation of his future labours in a solid scientifical method," id. at 34 . In discussing the law of property, he notes that while society is better off if the "mass of mankind" abstains from "scrutinizing too nicely" into the origins of private property, "when law is to be considered not only as matter of practice, but also as a rational science, it cannot be improper or useless to examine more deeply the rudiments and grounds of these positive constitutions of society." Id at vol. 2, 2. There is no explicit indication of a scientific approach in the general discussion of the common law of England that occupies $\S 3$ of the Introduction. Implicitly, however, one might glean an attempt to provide an orderly, "scientific" understanding from the taxonomical organization of $\S 3$. On the organization of the Commentaries, see generally Alan Watson, The Structure of Blackstone's Commentaries, 97 Yale L.J. 795 (1988) (explaining the historical roots of the Commentaries' organizational structure). 
examines the relevant precedents and customs in search of underlying animating principles that could serve as the ground of decision in the case before the court and even be extended to future cases. ${ }^{43}$ The cases are not (indeed, cannot be) themselves the law; ${ }^{44}$ they are only evidence of its operation, just as the movement of the planets evidences the operation of natural laws of attraction between bodies. Even the principles the cases announced might later be rejected (i.e., recognized as "not law") as experience under future facts and circumstances warrant.

Even if one accepts this as the intended (if not explicitly stated) account of what Blackstone had in mind, Blackstone's account of the authority of judicial decision-making in hard cases leaves much to be desired. Blackstone claims that the ground of authority for the common law is its status as longstanding and generally accepted custom. ${ }^{45}$ One may accept this claim with respect to cases that are clearly covered by "findable" precedents, but what gives judicial decisions their authority in those cases where the application of such authority as exists is uncertain? What makes the judge's decision in such a case, which by necessity involves a new declaration of the law, deserving of respect?

Blackstone's explicit answer to this question relies on a combination of appeals to mystery, oath-taking, reason, and judicial education and experience. It turns out, however, that judicial decisions are not always merely restatements of longstanding custom; rather, new decisions can themselves become "permanent rule[s]" which future judges are not free to disobey. If the issue being decided by a previous judge was "uncertain, and perhaps indifferent" before the decision was reached, the effect of that judge's action in the case is to establish a rule

43. Id.

44. Sir Matthew Hale provides an additional reason the decisions of the courts cannot be the law, although it does not square so well with Newtonian science:

The decisions of courts of justice ... do not make a law properly so-called (for that only the King and Parliament can do); yet they have a great weight and authority in expounding, declaring, and publishing what the law of this kingdom is, especially when such decisions hold a consonancy and congruity with resolutions and decisions of former times, and though such decisions are less than a law, yet they are a greater evidence thereof than the opinion of any private persons, as such, whatsoever.

Matthew Hale, History of English Law 56 (London 1739), quoted in Berman, supra n. 42, at 274.

45. Id. at vol. 1, 64 (legal customs "receive their binding power, and the force of laws, by long and immemorial usage, and by their universal reception throughout the kingdom."); see also id. at 67 :

[I]n our law the goodness of a custom depends on it's [sic] having been used time out of mind; or, in the solemnity of our legal phrase, time whereof the memory of man runneth not to the contrary. This is it that gives it it's [sic] weight and authority; and of this nature are the maxims and customs which compose the common law... of this kingdom. 
which it is not in the breast of any subsequent judge to alter or vary from ... : he being sworn to determine, not according to his own private judgment, but according to the known laws and customs of the land; not delegated to pronounce a new law, but to maintain and expound the old one. ${ }^{46}$

From the vantage point of the judge's authority, what is striking about all this is the capacity of a judicial decision to create a permanent rule where before there was none. In what sense is resolving an uncertainty or settling a previously "indifferent" but unresolved matter merely "maintain[ing] and expound[ing] an old law" rather than "pronounc[ing] a new [one]"? Blackstone does not elaborate on what it means to "maintain and expound" an old law. Presumably, "expounding" involves explaining the hitherto undeveloped consequences of the old law, while "maintaining" is suggestive of the requirement that there should be some degree of consistency and coherence between old decisions and new ones. This may well be the textual point of contact between Blackstone's official account and the Newtonian interpretation discussed above. Law is "the perfection of reason, ... it always intends to conform thereto[,] . . what is not reason is not law." ${ }^{, 47}$ Judges, then, can decide according to the law and not according to their individual preferences by exercising reason, including not only logic, but also observation and practical wisdom.

What is it, however, that gives this particular exercise of learning, experience and reason its authority as law? A previously uncertain application of a custom that is resolved in one direction or another cannot be supported by the authority of tradition (unless it is the tradition of abiding by the decisions of judges); and the resolution of an indifferent question is precisely the function Blackstone identifies as the main task of legislators, whose authority comes by delegation from the people. ${ }^{48}$ Moreover, if a new decision amounts to a "permanent rule," the source of which is the judge's decision rather than longstanding custom, there appears to be a shift from the unwritten law of custom to a written source, casting doubt on Blackstone's position that precedents are merely written evidence of an unwritten law.

46. Id. at vol. 1, 69 .

47. $I d$. at 70 .

48. Id. at 54-55. Blackstone also draws an analogy between the decisions of English judges and rescripts issued by the emperor in doubtful cases under the civil law system. See id. at 71 . Rescripts, once issued, became part of the law applied in future cases, see id. at 58-59. Blackstone disapproved of both the procedure of issuing rescripts and of their status as authority in subsequent cases. Id. 
If reason could be relied upon to produce uniform decisions among well-trained judges, so that the decisions in new cases are not just "private judgments" of individual judges, then perhaps all might be well. Law could get its authority from being the discovery of true underlying legal principles accessible to judges in their capacity as legal scientists. But it is not clear that Blackstone believes this to be the case. As already noted, precedent is the chief means by which judges are tied to the law rather than their own preferences. Blackstone emphasizes this point quite strongly. Even if there is no clear reason for an existing rule, and even if it works a seemingly undue hardship on a party in a present case, it is to be followed; this is necessary "[s]o that the law, and the opinion of the judge are not always convertible terms, or one and the same thing: since it sometimes may happen that the judge may mistake the law." 49

On the other hand, Blackstone implicitly gives individual judges a good bit of latitude in the way uncertain and indifferent questions are resolved. Precedents must be followed unless they are "most evidently contrary to reason" or "contrary to divine law." 50 This suggests an awareness on Blackstone's part that questions might "reasonably" have been decided, and rules of decision formulated, in more than one way. ${ }^{51}$ As noted above, these cases seemingly require the resolution of "indifferent" matters, which Blackstone identifies as one of the chief functions of the legislative branch. ${ }^{52}$

49. Id. at 71 .

50. Id. at 69-70. The passage is worth quoting in full:

For it is an established rule to abide by former precedents, where the same points come again in litigation;.... Yet this rule admits of exception, where the former determination is most evidently contrary to reason; much more if it be contrary to the divine law. But even in such cases the subsequent judges do not pretend to make a new law, but to vindicate the old one from misrepresentation. For if it be found that the former decision is manifestly absurd or unjust, it is declared, not that such a sentence was bad law, but that it was not law; that is, that it is not the established custom of the realm, as has been erroneously determined.

Id. (emphasis in original). Alschuler suggests that Blackstone is presenting the declaratory theory "with a wink and a nod." Alschuler, supra n. 1, at 37. See also id. at 37 n. 197 (noting Blackstone's use of "pretend" and suggesting that Blackstone could be read to suggest that the common law judges pretended not to change the law even when they did so); $f$. Storing, supra $\mathrm{n}$. 1 (Straussian reading of Blackstone).

51. Cf. Blackstone, supra n. 4, at vol. 1, 69 (referring to the resolution of "uncertain and perhaps indifferent" cases by courts); $c f . i d$. at 55 : “[T]hings in themselves indifferent . . become either right or wrong, just or unjust, duties or misdemeanors, according as the municipal legislator sees proper, for promoting the welfare of the society, and more effectually carrying on the purposes of civil life."

52. In the absence of precedent, the judge's decision is entitled to deference as long as it is not "contrary to reason... [or] the divine law," id. at 69-70, as long as it is "not flatly contradictory to reason," id. at 70, "not manifestly absurd or unjust," id., and not "repugnant to 
Blackstone cannot finally keep the legislative and judicial tasks separated. ${ }^{53} \mathrm{He}$ openly acknowledges that legislators make law, but on close examination, the distinction between the legislative and judicial roles turns out to be merely a matter of degree.$^{54}$ Neither legislators nor judges in Blackstone's order are completely unconstrained when they make laws; legislators must do no more than "declare" the law when they deal with matters impinging on natural rights and duties. Judges are limited not only by natural rights and duties, but also by statutes, precedent and the customs of the people. This is not an unimportant distinction, and Blackstone does present a picture in which judges are more constrained in their tasks than legislators are. Nevertheless, Blackstone's overall picture of the judicial role is out of balance; he emphasizes the consistency, uniformity and inherent reason of law, but only reluctantly and indirectly acknowledges the discretion that judges enjoy. ${ }^{55}$

\section{natural justice," $i d$. at 71 .}

In an earlier discussion having more direct application to legislation, Blackstone has said that all human laws depend upon the "foundation [of] the law of nature and the law of revelation ...; that is to say, no human laws should be suffered to contradict these." Id. at 42 . He affirms that laws are merely declaratory when they deal with matters covered by the law of nature and the Bible (which he equates elsewhere to natural rights and duties, see id. at 55), but have "their greatest force and efficacy" when they regulate the "great number of indifferent points, in which both the divine law and the natural leave a man at his own liberty; but which are found necessary for the benefit of society to be restrained within certain limits." Id. at 42 . With respect to these indifferent points, the sovereign is free to legislate as it "sees proper, for promoting the welfare of the society, and more effectually carrying on the purposes of civil life." Id. at 55. The sovereign is, however, required to respect natural rights, which "no human legislature has the power to abridge or destroy." Id. at 54 .

There is, then, a striking parallel between the rights and duties of the legislator and those of the judge. With respect to matters covered by natural and divine law (natural rights and duties), the sovereign's power is limited to the declaration of law, and positive enactments cannot alter these preexisting rights and duties: the legislature "acts ... in subordination to the great lawgiver, transcribing and publishing his precepts." Id. at 54 . The legislature's acts only have any real effect when they operate in the realm of "indifferent" matters, in which case they must be made with a view to the welfare of the society and not contradict natural rights and duties-i.e., they must not be contrary to reason or the divine law. Otherwise, the sovereign is free to do as it sees best. Even though Blackstone denies that judges make law, judges operating in a precedent-free zone have the same lawmaking authority legislators do.

53. One suspects Blackstone is aware of the incoherence. He notes that when courts make decisions in uncharted territory, the precedent is to be followed "because the law in that case being solemnly declared and determined, what before was uncertain, and perhaps indifferent, is now become a permanent rule." Id. at 69 (emphasis added).

54. See id. at 55.

55. A nineteenth-century parody of the Commentaries that appeared in Punch was not so reluctant:

The judges decide what is a custom and what is not. They, in fact, make the law, by saying what it means; which, as it is scarcely ever means what it says, opens the door to much variety. "Variety is charming," according to the proverb; and the study of law must, on this authority, be regarded as one of the most fascinating of occupations. "Law 


\section{EVANGELICALS AND THE BLACKSTONIAN TEMPTATION}

In some respects, evangelical attraction to Blackstone and his declaratory theory is surprising. The patrician Oxford law professor seems an unlikely hero for an historically populist movement. In addition, Blackstone's account of judge-made law relies extensively on the authority of tradition and natural reason - both of which evangelicals have frequently spurned as sources of moral authority in favor of God's authoritative revelation in the Bible. ${ }^{56}$

Evangelicals nevertheless have their reasons for defending Blackstone, and these reasons become clear when one examines what one must believe in order to take seriously a declaratory theory of law. Identifying some of the underlying assumptions of the declaratory theory helps explain why Blackstone's account of judging, improbable as it seems from the vantage point of induction, has been popular in some Christian circles.

The first thing a coherent declaratory theory requires is a belief in right answers. ${ }^{57}$ The right answers are the product of the exercise of reason, understood broadly to include not only clear thinking but presumably also accumulated practical knowledge and an ethical orientation consistent with true morality. ${ }^{58}$ These answers need not be the same in all jurisdictions; they may vary with surrounding conditions, including surrounding legal traditions. ${ }^{59}$ A second requirement is belief in the capacity of the judiciary to arrive at these right answers with some degree of regularity. Right answers must not only exist; they must also be knowable by the judiciary. ${ }^{60}$ In summary, declaratory theories can be

is the perfection of reason," say the lawyers; and so it is, when you get it; but if a judge makes a decision that is manifestly absurd or unjust, it is declared not to be law-for "what is not reason," say the lawyers, "is not law:" a maxim which, if acted upon, would have the effect of condensing the law most materially, or perhaps exterminating it altogether.

A'Beckett, supra n. 2, at 25.

56. On the respective places of Scripture, reason, and tradition in evangelical theology, see generally Keith A. Mathison, The Shape of Sola Scriptura (Canon Press 2001).

57. One can also imagine a version of the declaratory theory holding that legal reasoning may admit of more than one answer, even as it rules others out-of-bounds. See infra Part IV.

58. Blackstone actually seems skeptical about placing too much reliance on the judge's moral sense. In the realm of moral knowledge he holds that "undoubtedly the revealed law is (humanly speaking) of infinitely more authority than what we generally call the natural law. Because one is the law of nature, expressly declared to be so by God himself; the other is only what, by the assistance of human reason, we imagine to be that law." Blackstone, supra $\mathrm{n} .4$, at vol. 1,42 . He also emphasizes precedent and custom, both of which are "facts" that exist outside the realm of the judge's opinion. See id. at 69.

59. Blackstone's connection of the theory with English law rather than law in general suggests as much.

60. Interestingly, Blackstone's argument is double-edged. The legitimacy of judicial 
affirmed most easily by moral realists and epistemic optimists.

Blackstone's moral realism and his optimism about the human capacity to know the truth fit comfortably within evangelical presuppositions. Although Blackstone is pessimistic about the ability of fallen human beings to know moral truth apart from divine revelation, he believes that God has revealed himself in the Bible and he also believes in the clarity of the revelation contained therein. ${ }^{61}$ Like Blackstone, evangelicals believe that God has revealed His moral will for human beings in the Bible. ${ }^{62}$ Moreover, American evangelicals have tended to be quite optimistic about the capacity of human beings, aided by the Scriptures, to discern God's will in political matters. ${ }^{63}$

There may also be historical reasons for evangelical loyalty to Blackstone. Bentham, Austin, and the utilitarian opponents of Blackstone were certainly no friends of orthodox Christianity in the England of their time. More to the point, many of Blackstone's opponents in the American legal academy in the late nineteenth and early twentieth centuries were also advocates of a secularized vision of American law. ${ }^{64}$ Evangelicals may have risen to defend Blackstone because they have associated his decline with the decline of Christianity's influence on legal thought.

\section{THE DOCTRINE OF CREATION}

Despite the fact that evangelicals may have had some good theological and historical reasons for supporting the declaratory theory, my goal in this Part is to offer theological grounds for opposing it. I will

decisions is made to depend on their objectivity-the law's originating outside the judge. Accordingly, there is an assumption that the decisions of the judicial "oracles" represent the discovery of the law. The emphasis on precedent is entirely consistent with this approach, but it also rests on other grounds-the need for stability and the restraint of future judges. See id. On the other hand, the idea that the decisions are not law but merely evidence of the law preserves the flexibility necessary to make needed corrections, even as it implicitly casts doubt on the legitimacy of the judge-made law. If we obey the judges not because of what they decide but because they are "oracles" of law that is outside themselves, their capacity for error is a disturbing development.

61. Blackstone, supra n. 4, at vol. 1, 41-42.

62. See e.g. Exod 20:1-17; Richard J. Mouw, The God Who Commands (U. Notre Dame Press 1990).

63. See Noll, supra n. 11, at 149-177 (presenting a brief history of American evangelical reflection on politics). Noll also argues that evangelicals have been influenced by the Scottish Enlightenment's assumptions that "all humans possess[], by nature, a common set of capacitiesboth epistemological and ethical - through which they [can] grasp the basic realities of nature and morality." Id. at 85; see id. at 83-107 (tracing the development of evangelical thought).

64. See Stephen A. Siegel, John Chipman Gray and the Moral Basis of Classical Legal Thought, 86 Iowa L. Rev. 1513, 1515 (2001) (describing movement at Harvard to secularize law and Langdell's leadership). 
also explain why the declaratory theory's implicit idea of an unwritten civil law behind the law is problematic from a theological perspective. ${ }^{65}$ The theology of creation, especially when combined with the disjunctions between the declaratory theory and "bottom-up" accounts of law practice, ${ }^{66}$ ought to make orthodox Christians (including evangelicals) hesitant about endorsing the declaratory theory in its traditional form. Creation theology also points in the direction of an account of law that can both account for the particularity and diversity of

65. I have argued here that although Blackstone endorses natural law and divine law and connects law's authority to them, he does not view the task of the judge deciding a case as to search for an unwritten "law behind the law." See supra text accompanying nn. 36-39. Other proponents of the declaratory theory, such as Justice Story, however, are often read to characterize the judge's task as searching for the true unwritten principles of this law:

In the ordinary use of language, it will hardly be contended, that the decisions of courts constitute laws. They are, at most, only evidence of what the laws are, and are not, of themselves, laws. ... In all the various cases, which have hitherto come before us for decision, this court have uniformly supposed, that the true interpretation of the 34th section [of the Judiciary Act of 1789] limited its application to state laws, strictly local, that is to say, to the positive statutes of the state, and the construction thereof adopted by the local tribunals, and to rights and titles to things having a permanent locality, such as the rights and titles to real estate, and other matters immovable and intra-territorial in their nature and character. It never has been supposed by us, that the section did apply, or was designed to apply, to questions of a more general nature, not at all dependent upon local statutes or local usages of a fixed and permanent operation, as, for example, to the construction of ordinary contracts or other written instruments, and especially to questions of general commercial law, where the state tribunals are called upon to perform the like functions as ourselves, that is, to ascertain, upon general reasoning and legal analogies, what is the true exposition of the contract or instrument, or what is the just rule furnished by the principles of commercial law to govern the case. And we have not now the slightest difficulty in holding, that this section, upon its true intendment and construction, is strictly limited to local statutes and local usages of the character before stated, and does not extend to contracts and other instruments of a commercial nature, the true interpretation and effect whereof are to be sought, not in the decisions of the local tribunals, but in the general principles and doctrines of commercial jurisprudence. Undoubtedly, the decisions of the local tribunals upon such subjects are entitled to, and will receive, the most deliberate attention and respect of this court; but they cannot furnish positive rules, or conclusive authority, by which our own judgments are to be bound up and governed. The law respecting negotiable instruments may be truly declared in the languages of Cicero, adopted by Lord MANSFIELD in Luke v. Lyde, 2 Burr. 883,887 , to be in a great measure, not the law of a single country only, but of the commercial world. Non erit alia lex Romae, alia Athenis; alia nunc, alia posthac; sed et apud omnes gentes, et omni tempore una eademque lex obtinebit.

Swift v. Tyson, 41 U.S. 1, 18-19 (1842). This passage is a good bit more complex than Story's later critics tend to acknowledge. Cf. Guaranty Trust Co. v. York, 326 U.S. 99, 102 (1945):

Law was conceived as a 'brooding omnipresence' of Reason, of which decisions were merely evidence and not themselves the controlling formulations. Accordingly, federal courts deemed themselves free to ascertain what Reason, and therefore Law, required wholly independent of authoritatively declared State law....

(Frankfurter, J.).

66. See for example John Chipman Gray's famous attack on the declaratory theory. See Gray, supra n. 8, at 96-104, 219-232. 
human law and also leave a place for connection with an externally given moral order.

One of the statements of faith originating from within the Reformation tradition summarizes the doctrine of creation as follows:

It pleased God the Father, Son and Holy Spirit, for the manifestation of the glory of His eternal power, wisdom and goodness, in the beginning to create, or make of nothing, the world, and all things therein whether visible or invisible, in the space of six days; and all very good. ${ }^{67}$

This formulation of the doctrine emphasizes a number of points: the involvement of the Trinity in creation, the purpose of the creation as the manifestation of the glory of God, creation ex nihilo, ${ }^{68}$ creation of all things visible and invisible, temporal extension ${ }^{69}$ in the process of creation and the goodness of the world. ${ }^{70}$ The implications of the doctrine of creation are not immediately obvious, especially to readers (again, including Christian readers) in a culture for which the Christian idea of creation is foreign. The discussion below summarizes the salient features of the doctrine under four headings: contingency, dominion, the creator-creature distinction and eschatology.

\section{A. Contingency}

According to Christian teaching, the created world is contingent in

67. The Westminster Confession of Faith IV, 1 (1646) (available at www.pcanet.org/general/cof_contents.htm). The Reformers and the Catholic Church were in substantial agreement with respect to the doctrine of creation. See Richard A. Muller, The Unaccommodated Calvin: Studies in the Foundation of a Theological Tradition 39 (Oxford U. Press 2000):

[T] he Reformation altered comparatively few of the major loci of theology: the doctrines of justification, the sacraments, and the church received the greatest emphasis, while the doctrines of God, the trinity, creation, providence, predestination, and the last things were taken over by the magisterial Reformation virtually without alteration.

Within Christian circles, the most controversial feature of this paper's discussion of creation may be its emphasis on a particular understanding of creation's contingency. See infra Part III. A.

68. The doctrine of creation ex nihilo "affirms that God in creating the world relied on nothing outside himself." Colin E. Gunton, The Triune Creator 9 (William B. Eerdmans Publg. Co. 1998).

69. This refers to "the continuing action of God in upholding and directing the world he has made, and his action in completing that which was once begun." Id. at 88 . More simply put, the creation of the world, once begun, took time.

70. These elements continued to be emphasized in both Protestant and Catholic teaching. See e.g. The Catechism of the Catholic Church (pt. 1, § 2, ch. 1, art. 1, I 4, subpara. 290-292 (2d ed., Libreria Editrice Vaticana 1994) (creation is the work of the Trinity); id. at subpara. 293-294 (purpose of creation is the manifestation of God's glory); id. at subpara. 296-298 (creation ex nihilo); id. at subpara. 279 (creator of all things, visible and invisible); id. at subpara. 299 (goodness of creation). Interestingly, the temporal extension of creation does not appear to be emphasized in the Catholic Catechism. 
two respects: God need not have made the world in the way he did, and, indeed, he need not have made any world. The creation is contingent in the former sense because it was made "out of nothing." Thus, "God in creating the world relied on nothing outside himself, so that creation is an act of divine sovereignty and freedom." world out of something pre-existing, his freedom would have been constrained by that "something." As it is, God's design for the world was not constrained in any way.

Creation is contingent in the latter sense "[b]ecause... God is already, 'in advance' of creation, a communion of persons existing in loving relations." "72 He therefore "does not need the world, and so is able to will the existence of something else simply for its own sake." $" 73$ Again, God is free to shape the created order according to his good pleasure; creation was not a "necessary" act on God's part. Further, unlike God, the world is limited, having "a beginning in time and limited in space." 74 Together, these themes imply that the world is not a necessary emanation from God. Though related to God, it is also separate from him, "a realm of being in its own right."

What does this have to do with law? The contingency of the created order calls attention to that order's particular characteristics. If the world that exists and that we live in is contingent, its shape cannot be deduced in advance, whether on the basis of the nature of God's being, the nature of logical thought, the nature of eternal matter co-existing with God, or some other possible theoretical ground. Rather, the particular features of the world, including but not limited to laws, must be examined in order to be known. The fact that God is a God of reason and order does not require that every earthly law be "findable" in

\footnotetext{
71. Gunton, supra $\mathrm{n} .68$, at 9 .

72. Id.

73. $I d$.

74. Id.

75. Id at 10. According to Gunton:

"Contingent" has a number of distinct but related meanings. In the first, we say that the created order is contingent because it is dependent on God for its being. In that sense, there is little disagreement between different versions of the theology of creation. In the second, it is contingent because it happens to be the world that there is, but might not have been created, or might be otherwise than it is. This is an implication of voluntarism and an encouragement to [modern] science because it focuses questions on what is actually there rather than on what is ideally true. The third sense, which is closely related, is ... that because the structures of reality happen to be what they are . . - in order to understand the workings of the world one is bound to explore its actual material regularities rather than enquire into its underlying rational structures, as is the tendency of all Greek thought, Aristotle's included.
} 
timeless truths any more than God's freedom in creation suggests that lawmaking involves creation ex nihilo-the construction of rules out of nothing without reference to the created order of this world.

For all their differences, the most extreme Found Law and Made Law theories share an inability to conceive of a world in which there is room for both externally-given order and human freedom and where there are both meaningful universals and meaningful particulars. ${ }^{76}$ Yet, this is precisely the particular world both the Bible and human experience affirm. In Blackstone's Found-Law vision, judicial decisions are ideally the inevitable outcome of the operation of uniform, Godgiven reason. Their validity depends precisely upon their not bearing the mark of an individually identifiable decision maker-i.e., the judge, and thus the society, is capable of being "perfectly ruled.",77 Yet, it is precisely such uniformity that renders declaratory theories facially implausible.

Made Law theories, on the other hand, must be tempered in the light of genuine and seemingly intractable constraints on judicial freedom. Judges may make widely varying decisions, but "legal" values-like generality, promulgation, non-retroactivity, clarity and coherence $-{ }^{78}$ are pervasive. Even if one denies that there are inherent limitations on government authority, real-world legal systems are marked in fact by divided sovereignty, ${ }^{79}$ social norms that are not easily legislated around, and limitations on available means in cases where particular ends are desired to be accomplished. If freedom is defined as the absence of constraint, judicial freedom to make law is purchased at the price of others' freedom, whether the freedom of those being ruled or that of other branches of government. ${ }^{80}$

76. "Make yourself thoroughly, intuitively, master of the exceeding difficulties of admitting a one Ground of the Universe (which, however, must be admitted) and yet finding room for anything else." Samuel Taylor Coleridge, Letter dated April 1818, quoted in Colin E. Gunton, The One, The Three and The Many: God, Creation and the Culture of Modernity 21 (Cambridge U. Press 1993).

77. Cf. Arthur Allen Leff, Unspeakable Ethics, Unnatural Law, 1979 Duke L.J. 1229, 1229: "What we want, Heaven help us, is to be perfectly ruled and perfectly free, that is, at the same time to discover the right and the good and to create it."

78. See generally Lon L. Fuller, The Morality of Law 33-94 (rev. ed., Yale U. Press 1969).

79. See e.g. H.L. Hart, The Concept of Law 50-78 (2d ed., Oxford U. Press 1994).

80. Made Law theories arguably enhance the freedom of the ruled because they facilitate scrutiny of existing laws by displaying them as human artifacts that are often suboptimal or unjust. On the other hand, the tendency of Made Law accounts to treat justice and individual rights as merely conventional concepts can weaken resistance to oppressive rule. See Blackstone, supra $\mathrm{n}$. 4, at vol. 1, 70; $c f$. Thomas Aquinas, Summa Theologia IaIIae, Q. 96, art. 4 (trans., Fathers of the English Dominican Province, rev. ed. 1920) (Christian Classics 1981). ("[A]s Augustine says, a law that is not just, seems to be no law at all."). 
Again, despite their differences, the Found Law and Made Law positions share a discomfort with particularity. In both cases, individuals, whether they be judges or precedents, are more to be resisted than celebrated. As previously noted, the precondition for legal validity in Blackstone's declaratory theory is, effectively, the absence of an individualized, embodied judge. Similarly, precedents that seem illadvised to later judges are not simply overruled, but rather are negated entirely. The particular disfavored decision, it is said, never really existed; when the judge declines to follow it, it is not because it was bad law but because it was "not law" at all. ${ }^{81}$

One might think that Made Law conceptions do a better job of respecting particularity since they recognize the fact of judicial discretion and ascribe to judges a crucial role in legal decision-making. Nevertheless, real judges, litigants and particular legal decisions are also problematic in Made Law accounts. Once the Found Law pretense is seen through, the judge's place in the system is only as someone to be manipulated, engineered, and constrained by the larger power structure. $^{82}$ Often, the interests of "society" are privileged over those of the litigants in the evaluation of judicial decision-making. Neither the judge, the litigants, nor the precedent established by the case is deserving of any inherent respect. ${ }^{83}$

\section{B. Dominion}

The Christian tradition holds that part of the particular, contingent world God has made is the special relationship human beings have to that world. The human-world relationship can be summed up in the biblical concept of dominion: Human beings have been placed in a world which flourishes under their rule and, indeed, only under human rule. ${ }^{84}$ This idea is problematic given the modern tendency either to see "the human in terms of mind or will that is essentially different from nature" or to refuse any important distinction between human beings and the rest of the natural world. ${ }^{85}$

81. See Blackstone, supra n. 4, at vol. 1, 70; cf. Thomas Aquinas, Summa Theologia IaIIae, Q. 96, art. 4 ("[A]s Augustine says, a law that is not just, seems to be no law at all.").

82. See e.g. Jerome Frank, Law and the Modern Mind ch. XII (Coward-McCann, Inc. 1930) (discussing the judging process and urging judges to engage in ventures of self-discovery).

83. See e.g. Karl N. Llewellyn, A Realistic Jurisprudence-The Next Step, 30 Colum. L. Rev. 431 (1930) (urging a focus on sought-after behaviors and social interests rather than legal rules and remedies).

84. See generally Gen 1:26-28.

85. Gunton, supra n. 75, at 174 ("[S]ide by side have developed a view of the person as essentially indistinguishable from, identical in being with, the non-personal universe, and a view 
As a prelude to considering the importance of dominion for law, consider the uneasy relationship in modern thought between human beings and their physical environment. At one extreme, the non-human natural world is seen merely as a canvas on which humans create their own reality. As a "canvas," the non-human world has little importance in its own right; it is rather something to be mastered, a field within which humans operate to achieve their objectives without regard for the field itself. ${ }^{86}$ The human being is alien to the rest of the created order. Regrettably, the Christian idea of dominion is often associated, and not without reason, with such a view. ${ }^{87}$ At the opposite extreme is the drive to go as far as possible in eliminating the marks of human presence on the earth. The presence of human agency acting on "nature" is, on this view, inherently problematic because the ideal is a complete continuity between humanity and the rest of the natural order.

In contrast to either of these extremes, dominion presupposes human habitation of a particular, contingent God-made world that is intended to flourish in the context of human rule. Human rule, if faithfully executed, enables the world to be what it was created to be. Nature is intended to be the field of free human endeavor, but part of

of the person as so discontinuous with the matter of the world as to be an alien within it.").

86. Cf. Oliver O'Donovan, Resurrection and Moral Order 52 (2d ed., Wm. B. Eerdmans Publg. Co. 1994) ("Man's monarchy over nature can be healthy only if he recognizes it as something itself given in the nature of things, and therefore limited by the nature of things. For if it were true that he imposes his rule upon nature from without, there would be no limit to it.").

87. See e.g. Lynn White, Jr., The Historic Roots of our Ecologic Crisis, 155 Sci. 1203 (1967). White's article sparked an enormous and still continuing debate about the relationship between Christianity and our ecological problems. See Richard Bauckham, God and the Crisis of Freedom 128-133 (Westminster John Knox Press 2002) (citing sources). Bauckham argues that the Christian tradition may have paved the way for an excessively anthropocentric view of nature but would not have produced it by itself:

The dominant theological interpretation of the dominion in patristic and medieval times in some respects prepared the way for the modern scientific and technological project of conquering nature for human benefit, but it could not itself have provided the ideological support and motivation for that project. Only the significantly new interpretations given to the human dominion in Renaissance humanism and English Baconianism accomplished that. The crucial new elements were the understanding of the human dominion as a historical task, not a static condition of things but a mandate for progressive achievement of mastery over nature, to be accomplished by scientific discovery and technological innovation; the loss of an effective doctrine of creation, such that the human relationship to other creatures as fellow creatures gave way to an exclusively vertical relationship of humans to nature; and the reduction of the value of nature to the purely utilitarian, orientated only to practical human benefit.

Id. at 165. See also Thomas Sieger Derr, The Challenge of Biocentrism, in Creation at Risk? Religion, Science and Environmentalism 85-116 (Michael Cromartie ed., William B. Eerdmans Publg. Co. 1995) (defending stewardship as the appropriate metaphor for the relationship between the human person and the created order); but see Bauckham at 168-171 (arguing that stewardship is an excessively anthropocentric concept). 
that endeavor includes respect for non-human aspects of God's creation and recognition of divine ordering. As Oliver O'Donovan has written, human dominion is not "a crude struggle to stamp an inert and formless nature with the insignia of [human] will." It is rather "a worshipping and respectful sovereignty, a glad responsibility for the natural order which [the human being] both discern[s] and love[s]."${ }^{, 88}$

How does the idea of dominion assist in the articulation of a satisfactory conception of legal authority? An obvious objection to the invocation of dominion is that the term usually describes the relationship between humanity and the rest of the earth, not the rule of one human being by another. ${ }^{89}$ Nevertheless, the Bible uses dominion not only to refer to human rule over nonhuman creation, ${ }^{90}$ but also to describe human and divine rule over human beings. ${ }^{91}$ The concept of dominion points to a human rule that is not usurpation; human beings were made to "fill the earth and subdue it" and to "rule over" the living creatures on the earth. ${ }^{92}$ Yet, human rule was intended to produce not only humanity's flourishing, but also that of the earth itself.

Consider the normative account of kingship in the Old Testament. Israel's king is to be "one from among your brothers," and the king's rule is to be different from that exercised in Israel's neighbors. He is not

88. Oliver O'Donovan, Resurrection and Moral Order 52 (2d ed. 1994). Interestingly, one can detect some similarity between O'Donovan's late-twentieth-century account of dominion and that offered by Sir Matthew Hale.

Hale presupposes that nature left to itself would be chaotic: fierce animals would render the gentler and more useful animals extinct, the earth would be submerged in marsh and overgrown with trees and weeds. The earth needs a superior creature to keep it in order. Humanity's duty is therefore to keep things in balance, to prevent the wilder aspects of nature from creating chaos. Human beings are to control the earth for the earth's sake as well as for their own sake.

Bauckham, supra n. 86, at 170.

89. See Gen 1:26-28.

90. Ps 8:6-8.

91. See John Copeland Nagle, Christianity and Environmental Law, in Christian Perspectives on Legal Thought 435, 439-440 (Michael W. McConnell, Robert F. Cochran, Jr. \& Angela C. Carmella eds., Yale U. Press 2001). Images of just political rule and those of appropriate human rule over the environment are reinforcing to some degree. The example of God's own rule over humanity "belie[s] any suggestion that dominion [in the environmental context] equals exploitation." Id. at 439. Nagle emphasizes Jesus' equation of greatness with servanthood in Matt 20:26-28. See also Richard A. Young, Healing the Earth: A Theocentric Perspective on Environmental Problems and Their Solutions 170-177 (Broadman \& Holman 1994) (describing dominion in terms of kingship, servanthood and stewardship). Similarly, seeing the environment through the lens of divine creation arguably creates an emphasis on the continuity between human beings and the rest of the created order. Human beings are no doubt special in the Christian understanding of the world, but humans, plants and animals are together on the same side of the most fundamental theological distinction - that between the self-existent Creator and the world he has made. See infra Part III. C.

92. Id. 
to acquire excessive power or wealth, he is to remind himself of the law to which he is subject by writing for himself a copy of the law, which he is to keep with him and read in order "that he may learn to fear the Lord his God ...., that his heart may not be lifted up above his brethren, and that he turn not aside from the commandment."93 As Richard Bauckham observes, the king's "rule becomes tyranny the moment he forgets that the horizontal relationship of brother/sisterhood is primary, and kingship secondary." Bauckham uses this example to show that human dominion over the environment should be understood "as authority within creation, not over it." 94

Returning to the question of law, the critical point is again the fundamental conception of the human being as a creature and of the universe as a particular and contingent created place. Dominion in the political context is the limited, respectful rule appropriate to human beings given the kind of beings we are, the world in which we have been placed and our capacity for relationship with our Creator. ${ }^{95}$ The crisis of political authority confronting the West follows from an inability to conceive of a human rule (including, but not limited to, rule by judges) which is to some degree free, but is not merely an unjustifiable imposition of force. Thus, in the Made Law story, power is a zero-sum game. The ruler's freedom is either illusory - the sum total of the power constellation - or it is achieved at the expense of the ruled. The Found Law story shares this same fear of domination, but attempts to find a way out of it by attempting to imagine a world in which individual humans do not rule at all. Fear of domination is understandable and well-grounded given the track record of human rulers. Nevertheless, God's rule in Israel and in Christ provides a model for dominion that helps us to conceive of human rule - which is inevitable in the world as God has made it - as genuinely human and yet not an imposition. ${ }^{96}$

\section{The Creator/Creature Distinction}

As alluded to already, one of the most important features of the Christian doctrine of creation is the fundamental distinction between the Creator and his creatures. For present purposes, the two most important

93. Deut 17:14-20.

94. Bauckham, supra $\mathrm{n} .86$, at 174 .

95. Admittedly, this is only an analogy, for human rule over other human beings is not committed to human beings generically but rather to those whom God has appointed as "God's servant to do you good." See Rom 13:4.

96. See O' Donovan, supra n. 22, at 19-22 (arguing that the reign of God should be the starting point for political discourse). 
implications of the Creator/creature distinction are (1) that to be human is to be limited and (2) that the created order has its own separate (though entirely contingent) integrity.

Due recognition of human finitude is important because of the idolatrous pretensions to transcendence that accompany human rule after the Fall. Perhaps especially but certainly not only in the modern world, human beings need to be reminded of their limitations. Human beings are neither omniscient nor infinitely wise; human beings are not free in the way that God is free. Human habitation of a created world suggests that human beings were made to live in a world of space and time, and that to be human is inescapably to be embodied, to be geographically and temporally situated and to participate in particular (and therefore limited) cultural life. If human beings are limited in these ways, our civil laws need not be, indeed cannot be, universal and eternal. Neither particularity nor mutability renders human laws bad or deficient ${ }^{97}$ because God has declared the particular, limited created order "very good indeed." 98 Human laws are laws appropriate to human beings, in all their glory and all their limitation, in all the non-sinful variety that exists across time and cultures. Although judicial decision-making should both reflect and contribute to human flourishing, our judges need not be oracles of deeper realities inaccessible to the rest of us. ${ }^{99}$

The Creator/creature distinction also implies that the world has a reality that is distinct from God. Although it is dependent upon God, the created world has its own integrity and nature that is separate from God's nature and unlike it. This creates space for distinctively human law-law made by human beings, appropriate to its contingent, limited place and time, and serving human needs. One of the things human beings need is justice, defined even in the rather minimal sense of providing a public means of airing disputes and enforcing legal rights. Judging is one of the tasks God has given to human beings; and like other callings, it requires human beings to be active in the task. In this respect, human freedom in the judicial task is not only inevitable but,

\footnotetext{
97. Of course, such laws may be particular and mutable and may also be unjust or unwise.

98. Gen 1:31.

99. But cf. Planned Parenthood v. Casey, 505 U.S. 833, 868 (1992), where the Court notes: Like the character of an individual, the legitimacy of the Court must be earned over time. So, indeed, must be the character of a Nation of people who aspire to live according to the rule of law. Their belief in themselves as such a people is not readily separable from their understanding of the Court invested with the authority to decide their constitutional cases and speak before all others for their constitutional ideals. If the Court's legitimacy should be undermined, then, so would the country be in its very ability to see itself through its constitutional ideals. The Court's concern with legitimacy is not for the sake of the Court, but for the sake of the Nation to which it is responsible.
} 
within limits, something to be celebrated. God seems to have made a world in which, by his grace, human beings learn to administer justice and govern themselves in ways similar to the discoveries we make in technology, farming, and cultural matters, to name a few. ${ }^{100}$

Not unreasonably, human beings expect judges to demonstrate consistency and integrity in the administration of justice. This implies that decisions in one case have consequences for future cases and that, where records of such decisions are kept, a decision in one case will effectively influence the next. Again, as with other things human beings do, judging may be done well or poorly, virtuously or viciously. The stakes of judging are high because God has made a world in which human beings' actions are meaningful. There is no escaping the consequences of judges' decisions for litigants or for the law.

\section{Eschatology and Trinity}

A final element of the Christian theology of creation holds that the world is not just made by a god, but by God the Father, Son and Holy Spirit. This element reminds us that the world is part of a larger story. It has a purpose - the showing forth of the Triune God's glory-that is not fully accessible from within, and it thus cannot be fully comprehended from our limited vantage point. The Christian story focuses on Jesus of Nazareth, the second person of the Trinity, who took on human form in order to redeem the world. Among many other things, Jesus' incarnation teaches that God is related to this world not just abstractly, as in a deist conception of the designer of a watch or a building, but personally. God is involved with the world on an ongoing basis; he not only cares about the world he has made but is constantly holding it together by his power.

How is God's ongoing relationship with the world mediated? ${ }^{101}$ It is common in the Western tradition to picture God relating himself to the world by means of eternal principles or laws that serve as the blueprint for His creation and spell out its ongoing governance. ${ }^{102}$ This conception of the relation between God and the world may be more indebted to Greek philosophy than to the Bible. ${ }^{103}$ The primary picture of the ongoing God-world relationship in the Christian scriptures is found not in an eternal law (though Law is an immensely important

100. See e.g. Exod 31:3-4. I am not suggesting that law can be reduced to technological considerations.

101. See Gunton, supra n. 68, at 41-64 (discussing various theological accounts of mediation).

102. See e.g. Thomas Aquinas, Summa Theologiae IaIIae Q. 93.

103. See Gunton, supra n. 68, at 99-102 (criticizing Aquinas' account of mediation). 
theme of the Scriptures), but in an eternal Person who took human form and who entered the world in space and time personally and not through the abstraction of principle.

This faulty conception of mediation seems to have been carried over into our legal tradition, in which a law's legitimacy is frequently said to depend primarily upon its reason. ${ }^{104}$ It is worth noting that the New Testament generally speaks of our obligation to obey political authority in personal, rather than in legal, terms. All authority in heaven and on earth, we are told, has been given to Jesus Christ. ${ }^{105}$ In Romans 13, we are not told to obey just laws, but rather the human authorities. We are commanded to render to Caesar what is Caesar's, ${ }^{106}$ to honor the king, ${ }^{107}$ and to obey God rather than man when there is a conflict. ${ }^{108}$ There is no inherent conflict between a personalized account of legal authority and judicial processes that emphasize reason and rules. The Bible tells us to obey rulers (and thus rules) unless to do so would require us to disobey God. Rulers are accountable to God, and they receive their authority from him. ${ }^{109}$

This conception of personal rule is important because it reinforces aspects of human law and judging that are implied by other features of the doctrine of creation. ${ }^{110}$ Rule conceived in terms of personal agency opens up space for the possibility of valid human law that takes into account both human freedom and moral order. Human law can be authoritative without being eternal or unchanging or representing the mind of God. Personal rule is connected with the Creator/creature distinction discussed above: If we live in a world where God has ordained human rule, we can begin to understand human rule by recognizing that our rulers (including judges) are human beings. This means first that the judge is created and is not possessed of godlike reasoning power. He is limited, dependent, and fallen. Like other human beings in their callings, the judge's actions have important consequences in the world God has made. As a human being called to exercise juridical rule, the judge's decisions are real and reflect human

104. See e.g. Aquinas, ST IaIIae Q. 90, art. 1 (arguing that law is primarily a matter of reason). Recall that for Blackstone, judge-made law depends for its legitimacy on being based on longstanding custom or precedent. It is illegitimate only if it is "most evidently contrary to reason" or contrary to the divine law, Blackstone, supra n. 4, vol. 1, 69-70; otherwise judges and legislators have wide latitude.

105. Matt 28:18.

106. Matt 22:21.

107. 1 Pet $2: 17$

108. Acts 5:29.

109. Rom 13:1-4.

110. See supra text accompanying nn. 101-103. 
agency; they are not fully dictated by what has come before. As noted above, as in the other areas of life in which the human person exercises dominion, there is the possibility that the judge will do so faithfully and excellently, or unfaithfully or incompetently. In the latter case, her actions will potentially have negative effects on litigants, the community, and, indeed, the law and the jurisdiction's legal system. Because human beings live in community with each other, there is a certain irreducible vulnerability when magistrates exercise their rule wrongfully. Despite the best efforts of modern political philosophers to develop "stable" systems of political rule, this vulnerability cannot be entirely engineered out of the system. From a theological perspective, it is part of the tragic condition of a world awaiting the fullness of Christ's redemption. ${ }^{111}$

Similarly, a focus on the idea that the world is part of a larger story should put the story of the present (especially the political and legal present) in perspective. This claim may seem implausible, given the disproportionate emphasis some evangelicals have placed on politics in recent years. ${ }^{112}$ However, between Christ's advent and his promised future earthly rule, politics is destined to be temporary and provisional, as both history and Scripture attest. Although political ordering cannot be entirely unimportant to anyone who is concerned with the welfare of fellow human beings, political institutions are transitory. At their best, they can only anticipate dimly the shalom of God's final rule, which cannot be established mechanically through institutions but requires the spiritual defeat of "principalities and powers." "113

\section{TOWARD A TheOlogy OF Human LAW}

It is beyond the scope of this article to develop a full theology of

111. See e.g. O'Donovan, supra n. 22, at 46 :

That any regime should actually come to hold authority, and continue to hold it, is a work of divine providence in history, not a mere accomplishment of the human task of political service.... Behind every historically successful regime, there is the divine regime of history. The continuity achieved by the one presupposes the operation of the other, because it does not lie within the power of political orders to secure the social conditions for their own indefinite prolongation. ... (emphasis omitted).

112. For a regretful account of the emphasis the Christian right has placed on politics, see Cal Thomas \& Ed Dobson, Blinded by Might: Can the Religious Right Save America? (Zondervan Publg. House 1999).

113. See David VanDrunen, The Two Kingdoms: A Reassessment of the Transformationist Calvin, 40 Calvin Theol. J. 248 (2005); Marva J. Dawn, Powers, Weakness and the Tabernacling of God 1-34 (William B. Eerdmans Publg. Co. 2001); William Stringfellow, An Ethic for Christians and Other Aliens in a Strange Land 77-94 (Word Books 1973). 
human law. To do so would require not only fuller consideration of the theology of creation, but also attention to the nature of God, the human person, ethics, the consequences of the Fall, eschatology, and the relationship between the civil laws found in the Bible and political rule today. Nevertheless, the theology of creation is helpful in providing an understanding of why the declaratory theory is theologically deficient. In fact, it may also point toward a more satisfying account, theologically and empirically, of human law.

This account underscores that one can reject the declaratory theory and still affirm some of the truths that may motivate its continuing influence. Here, a central principle provided from creation theology is that only God has the capacity to create ex nihilo. Human beings cannot escape the given contingent creation, including its moral dimensions, as they make law, and they cannot but draw on their reason, moral sense, and technical capacities. One might regard these constraints as "laws" that should (or, in some cases, inevitably must) be followed in lawmaking and judging. For example, a judge who is deciding whether or not a prior precedent is controlling or distinguishable must reason and, in so doing, he will almost certainly make judgments about facts and their legal and moral relevance.

Another valuable claim that the declaratory theory has to offer is the possibility that there might be true legal concepts to be discovered ${ }^{114}$ - true in the sense that they correspond to the particularities of our world, including human longings for justice. The presence across cultures of norms against murder, theft, adultery, and lying and expectations about the judicial process itself suggest an element of discovery and declaration. ${ }^{115}$

One suspects that one of the reasons the declaratory theory holds such attraction for believers in a personal God is that it seems possible, indeed likely, that the right answer to legal questions exists in the mind of God. The God of the Bible is aware of the details of the world and concerned about them. ${ }^{116}$ Surely he has an opinion about the best resolution of such matters and is glorified when human beings decide as he would. It seems only logical that ideal human law consists of the answers God would give to these questions, ${ }^{117}$ and the good judge is the

114. Cf. O'Donovan, The Desire of the Nations, supra n. 22, at 12-21 (arguing that political theology requires "true political concepts").

115. Similarly, the idea that decisions are not the law might be taken as evidence of humility in the face of our question for justice. Nevertheless, as argued earlier, this view seems to understate an appropriate human role in the construction of human law.

116. Matt 10:29-31.

117. Cf. Gray, supra n. 8, at 97 (positing the legal opinion of "an all-wise and all-good 
one who discovers those answers and declares them.

Intuitive as this seems, there are reasons to question whether such a model of the judicial activity is theologically authorized. When he was asked to resolve a quintessentially legal property dispute, Jesus pointedly declined. "Who," he asked, "appointed me a judge between you?" 118 Perhaps God deems it best for us not to be told the full answers, leaving us free-against the backdrop of a world we did not make and cannot fully alter - to experiment with, discover, devise-or perhaps even despair of finding - just legal and political arrangements. As suggested above, judging and legislation may be like carpentry, farming, painting, music, or engineering in the sense that we learn more by doing and experimenting than from direct revelation. The same logic that would submit every legal question to the mind of God would submit every painting, pasture, or sonata to God's hand-short-circuiting the distinctly human quest for achievement in these areas, a quest that is presumably built into the created order.

Even if it turns out that there is a single best answer (in the sense that there is an answer that God would choose), it is questionable whether it is useful to identify the divinely chosen answers as the law and the human decisions as merely rebuttable evidence of the law. One reason for this is simple: we have access to the human decisions, but God has not given us his answers to most legal questions. Further, the Bible does not teach that human rulers (who hold office by God's providence) must have access to God's answers in order for their decisions to be authoritative. Indeed, as we have seen, the idea of a created order that is separate from its Creator and has its own integrity opens up space for conceiving of a legal order that is distinctively human. This need not imply that such rulers are morally unaccountable in their decision-making.

Furthermore, most Christians have not read the Bible to prescribe any particular form of human government, much less any particular conception of the judicial role. ${ }^{119}$ The contrasting judicial roles in the civil law and common law systems are perhaps the most familiar example for Western readers. Presumably the modes of "law-finding" would vary from one system to another, and with them, the ideal law that should be declared. Moreover, different cultures undoubtedly

intelligence" as a standard against which positive law can be measured).

118. Luke 12:13-15.

119. On the wisdom of withholding theological warrant for such matters, see generally David M. Smolin, Church, State, and International Human Rights: a Theological Appraisal, 73 Notre Dame L. Rev. 1515 (1998). 
ascribe different weights even to values all would agree are good-e.g., stability and respect for tradition vs. improvement in existing social and legal arrangements. These factors do not negate the possibility of a divinely known best answer. ${ }^{120}$ However, they are suggestive of a greater emphasis on human freedom in lawmaking than is implied by the declaratory theory.

There are two other theological reasons for thinking that the declaratory theory tends to underemphasize the human role in lawmaking. First, for better and for worse, God regularly involves human beings in the accomplishment of his purposes for the world, and many of the things human beings do-particularly the most challenging things - reflect something of the individuality of the person doing them. In the Christian tradition, human vocations, including lawyering and judging, are intended to be venues for worship, service, and delight in God. As such, the lawyer or judge's personhood is reflected in the response of love for God and neighbor, or lack thereof, that is brought to the task. In the particular world God has chosen to make, human beings have an indispensable role in the establishment of civil justice. The declaratory theory suggests that the judge's role is to become invisible and impersonal in the course of judicial decision-making. The positive side of this account is to reinforce law's objectivity and authority. Nevertheless, the doctrine of creation helps us see how law might be authoritative without presupposing that the human beings who make and administer it are irrelevant to the tasks they perform.

Finally, the Christian story is ultimately about the glory of God, who demonstrates his love by redeeming rebellious human beings from sin and bondage at the greatest imaginable personal cost. Perhaps, in the time between Christ's advent and his consummation of all things, earthly political and legal rule is a reminder of our common longing for things to be set right. The Christian hope is that we will be better off when perfect political rule is exercised by the exalted Christ. Perhaps one of the purposes of the law is to remind us that, despite our best efforts, our politics and our law are still dramatically in need of that redemption.

J.R.R. Tolkien believed that "[t]rue Creation is the exclusive province of God."121 In his view, it is within our power only to "make

120. Assuming such political and cultural diversity is part of God's will, God could be assumed to know the best legal answer under the circumstances, even if the answers to similar questions are not uniform across legal systems and cultures. Definition of Leaf by Niggle, http://www.wordiq.com/definition/Leaf_by_Niggle (accessed Dec. 1, 2006).

121. Id. See generally J.R.R. Tolkien, Tree and Leaf (Houghton Mifflin Co. 1965) (explaining 
echoes (good) or mockeries (evil) of truth. The Subcreation of works that echo the true creations of God is one way that mortals honor God." "122 Just as in the Silmarillion, one Vala makes dwarves in a pleasing echo of the divine action and another makes Orcs as a mockery of elves, ${ }^{123}$ so in our system judges can and do make laws, and those laws may be-to paraphrase Tolkien-either echoes or mockeries. Judge-made laws may be dwarves or orcs, but they are real in either case.

and illustrating Tolkien's account of subcreation).

122. Definition of Leaf by Niggle, http://www.wordiq.com/definition/Leaf_by_Niggle (accessed Mar. 28, 2007). See generally J.R.R. Tolkien, Tree and Leaf (Houghton Mifflin Co. 1965) (explaining and illustrating Tolkien's account of subcreation).

123. J.R.R. Tolkien, The Silmarillion 43-50 (Christopher Tolkien ed., Houghton Mifflin Co. 1977). 